\title{
AN EMPIRICAL INVESTIGATION OF THE IMPACTS OF CARBON TAX ON ECONOMIC GROWTH IN NIGERIA
}

\author{
Alhassan Mohammed Aminu \\ Department of Economics and Development Studies, \\ Federal University Dutsin-Ma, Katsina State - Nigeria \\ Email: maalhassn@fudutsinma.edu.ng/alhassanmohammed58@yahoo.com

\section{Hadi Aminu} \\ Department of Economics and Development Studies, \\ Federal University Dutsin-Ma, Katsina State - Nigeria \\ Email: ahadi@fudutsinma.edu.ng/aminuhadi85@gmail.com
}

Corresponding Author Email: alhassanmohammed58@yahoo.com

\begin{abstract}
:
This study is designed to investigate the anticipated impact of carbon tax on economic growth in Nigeria using the scenario of the proposed tax rate on the primary carbon emission-related activities. This study therefore employed ARDL bound test and Toda-Yamamoto causality tests to show the existence of long-run relationship between carbon tax and economic growth. The study therefore revealed that: carbon tax has positive impact on economic growth; governance has negative impact on economic growth: non-existence of causal relationship between carbon tax and economic growth in Nigeria. Hence, the study recommended among others, upward review of carbon tax and strict adherence to the regulation of tax rate on carbon emission be enforced, as well as consideration for application of tax rate on other non-primary emitters of carbon in Nigeria.
\end{abstract}

Keywords: Carbon Tax and Economic growth. 


\section{Introduction}

The take-off stage of growth theory postulated by Rostow theory of growth is characterised by the progression in industrialization which is accompanied by upsurge in environmental mutilation induced by more exploration and exploitation of natural resources, and manoeuvre of less efficient and relatively filthy technologies as well as neglect of the environmental consequences for growth, propelled discharge of more pollutions that is hazardous to the natural environment (Garber, 2011). To this end, environment and its dwellers are threatened by increasedpollution dischargesdue tocarbon emission and greenhouse gas concentration in atmosphereas a form of externalities that aregenerated from industrialization process thereby risingthe greenhouse effect and subsequent climate change that have assumed complex universal environmental issue nowadays.Pollution is basically as a result of carbon emission (Grossman, 2009).

In this direction, Nigeria has in the recent past years been overstrained by vast of human activities in environment giving rise to impending concerns about environmentally related issues, both in the facet of quality and quantity environment. Deforestation, soil degradation environment pollutions made part of earlier raised environmental concerns in Nigeria (Stephen, 2014). Consequently, the effects of pollution resulted from carbon emissions-generated activities have been devastating, disturbing to both the environment and human beings occupying the environment, and this subsequently hampersthe goal of attaining the growth of Nigerian economy (Chindo and Abdul-Rahim, 2018). Accordingly, Article 13 of the Sustainable Development Goal of the United Nations was explicitly clear on the need for exigent actionsto combatpollution like carbon emissions and itsensuingimpacts on environment by regulating emissions-related activities in order to promotegrowth and developments in the face of renewable energyin Nigeria (United Nations report, 2015).

Form the foregoing, bearing the multidimensional pressures of pollution particularly carbon emissions that is exacerbating environmental threats in the prone areas in Nigeria and the needs to curtail the impending dangers of carbon emission on Nigerian environmental space, Nigeria alongside other international economies found it noteworthy that carbon tax is one among other most important measures to drive a safer climate that would promote a more secured and healthy economy for the sustained growth of the economy (Bowen, 2011; Lütken, Fenhann, Hinostroza, Sharma and Olsen, 2011). Consequently, a robust, expectable and growing explicit carbon price, specifically carbon tax aiding the consumption choices and investments towards low-carbon activities, in order to shift away from carbon-intensive ones and source of raising revenue for the growth purposes is applied through policies appropriate to the national context (OECD, 2015).

To this effect, Federal Government of Nigeria enacted CarbonTaxAct in June 2019 as a policy tool designed to accomplish the targets of safe and healthy environment througheffective regulation of the emission of pollution generatingactivities into the environment as an impulse to effectively guarantee low carbon economy and also a means of diversifying source of revenue generation for the economy (Baranzini and Carattini, 2014; Parry, Heine, and Veung, 2015; KPMG, 2015). From the foregoing, the introduction of carbon tax is perceived as a new subject in the field of energy economics by some of the developing economies particularly, Nigeria and that compels empirical investigation of its impact on the economy. Thus, this study seeks to investigate the impact of carbon tax on the growth of Nigerian economy and causal relationship between carbon tax and economic growth in Nigeria. 
Following the introduction given in the section one; the section two ccomprises literature review; section threedeals with methodology of the study; while section four presents analysis of the results, interpretation and discussion, and section five concludes the study and offers possible recommendations.

\section{Literature Review}

\subsection{Definition of Key Concepts}

\subsubsection{Carbon Tax}

Generally, carbon tax isa policy tool targeted to abatethe effects of environmental deteriorationcaused by some activities of companies in energy and transport sector forconsiderably mitigating the rate of carbon emitted to an economy (Mojtaba, Alireza and Mehdi, 2020). Therefore, a carbon tax is a fee levied by government on company or sector (mostly transport and energy sector) that burns carbon content of fuelslike coal, oil, gasoline, and natural gas, which like carbon emissions trading, is a form of carbon pricing based on the ton of emitted carbon (Kalkuhl, 2013). Similarly, Al-Abdullah (1999) defines carbon tax as a charge imposed on carbon emissions-generatingactivities caused by fossil fuel consumption, which also serve as revenue to the state.

\subsubsection{Economic Growth}

There is general consensus among the scholars on the operational definition of economic growth to mean an increase in the quality and quantity of resources in an economy (Alhassan, 2018; Egwu, 2018; Haller, 2016; Orugbani, 2011). Therefore, economic growth according to (Haller, 2016) is a process of increase in the magnitude of national economies, with macroeconomic indications, especially per capita Gross Domestic Product (GDP), in an upward but not necessarily linear direction, with positive effects on the economic and social part of the economy. Similarly, Udeh, Okoroafor and Ihezie (2013) conceptualized economic growth as an increasing capacity to fulfil the needs and wants of the economy overtime. It is therefore conventionally measured as the percentage rate of increase in real gross domestic product, or real GDP.

\subsection{Overviews of Carbon Tax Acts in Nigeria.}

Following the global commitment to actualize greenish atmosphere and subsequent desire of Nigerian government to abate the effects of pollutions resulted from carbon to the bearable minimum on Nigerian economy without hampering the productive capacity of the country's manufacturing sector by imposing carbon tax on carbon emission related activities to supplement for environmental defects due to carbon emissions, Carbon Tax Act was ratified (Opeyemi, Philip, Oluseyi and Henry, 2017). Carbon Tax Act was brought about as requisite to adjust and preserve the natural environment from the impeding danger of carbon related activities in the country and to increase diversification of revenue base for the country.

In this regards, the companies and activities that are identified to run emission generating services are by the Act regarded as carbon taxpayers paying tax for emitted carbon to an economy to compensate for the depletion of valuables from natural environment (KPMG, 2015). Though in the Carbon Tax Act, the stresses are given to primary emitters of carbon and greenhouse gas, and thus, the carbon tax is set at rate of R120 ( $\$ 2,462.4)$ per ton of carbon equivalent, less certain allowances, taking into account such allowances while setting the tax 
rate, the real rate per ton of carbon emitted is then left at the range of R48 (N984.96) per ton of carbon emission (Precious, 2017). Interestingly, the establishmentofCarbon TaxActwas of three different implementation phases. Whilst phase one will imposetax on certain industries and bbusinesses that are regarded as direct primary emitters; phase two will in addition to the activities taxed in phase one includes taxing indirect emissions and phase three will also containtaxing the supply chain activity that is likely to impact on all business activities and economy. Carbon tax will apply to fuel burning; fugitive emissions from fuels; and industrial processes emissions.

\subsection{Theoretical Framework}

\subsubsection{The Benefits-received Theory:}

This theory was developed by Knut-Wicksellin 1896 and refined by Erik-Lindahlin 1919 which was further restated by Paul-Samuelson(Richard and Peggy, 1973; Bernd, 2000). The input of the theorywas based on the premise that, there is basically an exchange or contractual relationship between taxpayers and the state. Therefore, imposition become necessary in order to aid the state to provide or supply certain public goods and services like secured environment, schools, basic health facilities and infrastructures, among others to the citizenry; while citizenry in returncontribute for the cost of these supplies in proportion to the benefits received (Bernd, 2000). In this quid pro quo set up relationship, tax revenue is a means to the government to pursue the growth and development goals to the society. Concisely, this theory bears the possible use of the tax policy for bringing about economic growth and economic stabilization (control of externalities from hampering the natural environment) in the country. This study is therefore hinged on the principle of benefit-received theory for the presence of mutualreinforcing relationship between the taxpayers and tax recipients (government) to sustain the anticipated growth of the Nigerian economy.

\subsection{Empirical Reviews}

The concept of carbon tax in Nigeria is still a fresh subject under the broad specialization of energy economics that is currently attracting attention of academic scholars and researchers to analysing its impacts on economic growth and as such, there exist scanty empirical studies in literature in Nigeria. Therefore, this study shall review literaturesbasedonempirical studies in countries that have had carbon policy for years towards enhancing the growth of economy.

Consequently, an empirical study of the relationship between carbon emission and economic growth and openness for the sampled countries (China, Korea and Japan) by Eunho, Almas and Yongsung (2010) used VAR and VECM as the method of analysis and revealed that the environmental consequences resulting from carbon emission on economy is not uniform across the sampled countries, hence there is large heterogeneity among the countries and variables impacts on economy. Likewise, a study by Lin and Li (2011) on the impact of a carbon tax on carbon emissions per capital for five Northern European countries utilizing Difference-InDifference method of analysis and revealed that carbon tax can induce the desired eff ect of less energy consumption and a shift of the economy to renewable energy sources and the growth of economy. Though, there is variation in the magnitude and statistical significance of the results among the examined countries owing to the different tax rates among the countries.

Also, a study by Stephen (2014) on the impact of carbon emissions on economic growth in Nigeria between 1980 and 2010 utilised OLS to revealed negative impact of carbon emission on 
economic growth in Nigeria. Similarly, Castiglione, Infante, Minervini, andSmirnova (2014) studied the effects of production, consumption, environmental quality and government quality on environmental taxation for 24 European Union countries that are classified into three categories, namely; market economies featured by advanced industrial and services sectors; under-developed economies and transition economies. The study utilized panel data analysis method on data obtained from the studied countries to reveal that the environmental tax revenues of the respective countries are significantly affected by the level of development and government quality of the respective economies.

Furthermore, Guo, Zhang, Zheng and Rao (2014) studied the magnitude to which carbon taxes affect China's economy and carbon emissions based on China's input-output tables for the year 2010. Using a generalized equilibrium model, the study shows that a reasonable carbon tax reduces carbon emissions and demand for fossil fuel energy. Likewise, Andersson (2015) studied the impacts of the carbon tax and environmental value added tax levied in 1991 to reduce carbon dioxide emissions in Sweden economy between 1990 and 2005. Adopting synthetic control methods, the study established that the levied carbon tax reduces carbon dioxide emission in Sweden and consequently guarantee safer economy under which the growth of economy is pursued.

Saidi and Hammami (2015) investigated impact of carbon emission and economic growth on energy consumption in 58 countries that are grouped under four panels (that is, Europe and North Asia, Latin America and Caribbean, and Sub-Saharan, North African and Middle Eastern) between 1990 and 2012. The study utilized GMM technique to reveal the existence of positive and significant impacts of both carbon emission and economic growth on energy consumption for the four global panels. More so, Mesih and Mesih (2009) established in their study that carbon emissions from gas flaring or gas fuels and solid fuels have positive and significant impacts on economic growth.

\section{Methodology}

\subsection{Data Sources and Description}

The study employed secondary data spanned for the period1990 to 2018. The data was obtained from CBN (2019), ICRG (2017) and CAIT (2017). Though, the study adopts four years progressive moving average to make up for the missing points from CAIT (2017) and ICRG (2017) dataset. Based on the theoretical framework, economic growth is a function of ability of state to pursue a secured environment under which economic growth is to be achieved in a sustainable manner through imposition of carbon tax as revenue to the state for growth purposes. However, the lack ofdataset for carbon tax in Nigeria necessitated the use of proposed carbon tax rate $(\mathrm{R} 48=$ 984.96) per ton of carbon emission (see Carbon Tax Act, 2019) to compute the dataset for carbon tax based on the available dataset on all categories of primary carbon emissions such as building, electricity, manufacturing, construction and other fuel carbon, among others; while RGDP is used to measureeconomic growth.

\subsection{Model Specification}

Following the extant literature, a model is specified to investigate the impact of carbon tax on economic growth in Nigeria. The empirical model is presented as follows:

$\mathrm{RGDP}=\mathrm{f}(\mathrm{CT}, \mathrm{GOV})$ 
Where;

RGDP = Real Gross Domestic Product;

$\mathrm{CT}=$ Carbon tax and;

$\mathrm{GOV}=$ Governance.

Governance is introduced into the model because, for tax administration to be effectively translated into desired growth, good governance system is an impetus. Therefore, restatement of equation (1) in an economic model to encompass error term is specified as:

$\mathrm{RGDP}=\alpha+\beta_{1} \mathrm{CT}+\beta_{2} \mathrm{GOV}+\varepsilon_{\mathrm{t}}$

Such that $\beta_{1}>0, \beta_{2}>0$

\subsection{Model Estimation Procedure}

Firstly, the stochastic properties of variables employed in the study were investigated using Augmented Dickey-Fuller unit root test framework which then aid the choice of the appropriate econometric technique used for analysis. The choice of ADF unit root is due to its greater reliability of estimated $t$-statistics (Min and Guna, 2018). The test for unit root for variables with both trend and intercept is carried out using the following specification:

$\Delta \mathrm{RGDPt}=\alpha_{0}+\beta_{1} \mathrm{RGDP}_{\mathrm{t}-1}+\beta_{2} \mathrm{~T}+\sum_{i=0}^{n} \varphi i \Delta \mathrm{RGDP}_{\mathrm{t}-1}+\varepsilon_{\mathrm{t}} \ldots \ldots \ldots \ldots \ldots$ (3.3)

Where, $\beta_{0}, \beta_{1}, \beta_{2}$ and $\varphi i \ldots \varphi_{\mathrm{n}}$ are parameters to be estimated, and $\varepsilon_{\mathrm{t}}$ is the disturbance term.

The unit root test was followed by cointegration test using the ARDL cointegration test framework due mainly to the mix order of integration of the variables (that is I/0 and I/1) in the model and its applicability to small sample size (Pesaran, Shin and Smith, 2001). Thus, ARDL cointegration model is specified as:

$$
\Delta \mathrm{GDP}_{\mathrm{t}}=\phi_{0}+\delta \mathrm{GDPt}_{-1+} \delta_{2} \mathrm{GOV}_{\mathrm{t}-1}+\sum_{i=1}^{i} \Delta \mathrm{GDP}_{\mathrm{t}-i}+\sum_{i=1}^{i} \Delta \mathrm{GOV}_{\mathrm{t}-i}+\varepsilon_{\mathrm{t} \ldots} \ldots \text { (3.4) }
$$

Upon examination of stochastic properties of the series and subsequent establishment of the presence of cointegrating relationship between the examined variables, Auto-regressive distributed lagged model (ARDL) was then chosenas the suitable estimation technique for this study. Thus, the ARDL regression model is specified as:

$\mathrm{RGDP}=\alpha+\beta_{1} \mathrm{CT}_{\mathrm{t}-1}+\beta_{2} \mathrm{GOV}_{\mathrm{t}-1}+\delta_{1} \mathrm{CT}_{\mathrm{t}-1}+\delta_{2} \mathrm{GOV}_{\mathrm{t}-1}++\varepsilon_{\mathrm{t}} \ldots \ldots \ldots \ldots$ (3.5)

Subsequent to the establishment of long-run relationship among the examined variables implies that there is tendencyfor deviation of either jointly or independently from the established longrun equilibrium state by variable(s) that is thus corrected by the degree of adjustment and such degree of adjustment is captured by the short-run equilibrium dynamics model otherwise referred to as ECM (error correction model) (Emeka and Aham, 2016). Therefore, the ECM model is specified as;

$\Delta R G D P_{t}=\beta_{0}+\sum_{i=1}^{n} \beta_{1} \Delta R G D P_{t-1}+\sum_{i=1}^{n} \beta_{2} \Delta G O V_{t-1}+\pi_{1} E C T_{t-1}+\varepsilon_{1 t} \ldots$ (3.6) 
Theoretically, the presence of long-run equilibrium follows that; there is tendency for either unidirectional or bi-directional granger causality to exist between the examined variables. Thus, the granger causality model is specified as:

$$
\begin{aligned}
& \operatorname{RGPD}_{\mathrm{t}}=\beta_{0}+\beta_{11} \mathrm{RGDD}_{\mathrm{t}-1}+\ldots+\beta_{1 \mathrm{p}} \mathrm{RGDD}_{\mathrm{t}-\mathrm{P}}+\mathrm{C}_{11} \mathrm{CT}_{\mathrm{t}-1}+\ldots+\mathrm{C}_{1 \mathrm{p}} \mathrm{CT}_{\mathrm{t}-\mathrm{P}}+\mathrm{U}_{1 \mathrm{t}} \ldots \ldots \ldots . . \\
& \mathrm{CT}_{\mathrm{t}}=\beta_{0}+\beta_{21} \mathrm{CT}_{\mathrm{t}-1}+\ldots+\beta_{2 \mathrm{p}} \mathrm{CT}_{\mathrm{t}-\mathrm{p}}+\mathrm{C}_{21} \mathrm{RGDD}_{\mathrm{t}-1}+\ldots+\mathrm{C}_{2 \mathrm{p}} \mathrm{RGDD}_{\mathrm{t}-\mathrm{p}}+\mathrm{U}_{2 \mathrm{t}} \ldots \ldots \ldots \ldots \ldots .
\end{aligned}
$$

\subsection{Diagnostic Tests}

The diagnostics include tests for autocorrelation, misspecification, normality, heteroscedasticity and stability of estimated coefficients were also conducted to ascertain that the estimated model is free from spurious result.

\section{Results and Discussions}

\subsection{Presentation of Results}

The trend analysis of the variables employed in the study revealed the pattern of the data over the years as explicitly shown in appendix (I). Noteworthy, the estimated carbon tax is a result of computed tax rate per ton of carbon from the aggregated carbon emitted from six primary emitters of carbon as shown in the respective figure in appendix (i).

Also, the result of correlation matrix as shown in appendix (II) revealed that there exit positive but weak correlations matrix between carbon tax and economic growth; while weak and negative correlation matrix exist between governance and economicgrowth, because the correlation coefficients between the variables are farther from one (1) as shown in the correlation matrix table.

\subsection{Pre-estimation Test}

Table4.1: The Result of Unit Root Test

\begin{tabular}{|l|l|l|l|l|}
\hline Variables & Order of integration & Critical Values (ADF) & Prob & Decision Rules \\
\hline RGDP & $\mathrm{I}(0)$ & $-4.297882^{*}$ & 0.01 & Stationary \\
\hline InCT & $\mathrm{I}(1)$ & $-5.403635^{*}$ & 0.00 & Stationary \\
\hline GOV & $\mathrm{I}(0)$ & $-3.765411^{* *}$ & 0.03 & Stationary \\
\hline
\end{tabular}

Sources: Author's Computation

Note: $(* * *),(* *)$ and $(*)$ indicates statistical significant at $10 \%, 5 \%$ and $1 \%$ respectively.

The table 4.1 shows the result of ADF unit root test. As shown in the table, economic growth (RGPD) and GOV were stationary at level (I/0). Though economic growth (RGDP) is stationary at levelbut at $1 \%$ level of statistical significance; while governance (GOV) is stationary at level but 5\% level of statistical significance. However, carbon tax (InCT) only became stationary after taking the first difference and at $1 \%$ level of statistical significance. The verification of unit root tests was followed by the test for cointegration using ARDL approach developed by Pesaran, Shin and Smith (2001) in order to investigate the long-run equilibrium relationship between the examined variables. Thus, the result of cointegration test is given in the below table. 
Table4.2: Results of Cointegration Test

\begin{tabular}{|c|c|c|c|c|c|c|c|}
\hline \multicolumn{2}{|l|}{ Dependent Variable } & \multicolumn{3}{|c|}{ Function } & \multicolumn{2}{|c|}{ F-Statistic } & K \\
\hline \multicolumn{2}{|l|}{ INS. } & \multicolumn{3}{|c|}{$\mathrm{f}(\mathrm{RGDP} / \mathrm{InCT}, \mathrm{GOV})$} & \multicolumn{2}{|c|}{$4.809776 * *$} & 2 \\
\hline \multicolumn{8}{|c|}{ Critical Values Bounds } \\
\hline $10 \%$ & & $5 \%$ & & $2.5 \%$ & & $1 \%$ & \\
\hline $\mathrm{I}(0)$ & $\mathrm{I}(1)$ & $\mathrm{I}(0)$ & $\mathrm{I}(1)$ & $\mathrm{I}(0)$ & $\mathrm{I}(1)$ & $\mathrm{I}(0)$ & $\mathrm{I}(1)$ \\
\hline 2.63 & 3.35 & 3.1 & 3.87 & 3.55 & 4.38 & 4.13 & 5.0 \\
\hline
\end{tabular}

Source: Author's Computations.

Note: $(* * *),(* *)$ and $(*)$ indicates statistical significant at $10 \%, 5 \%$ and $1 \%$ respectively.

In estimating the ARDL model, the Akaike Information Criterion (AIC) demonstrates that the optimal lag-length for the variables is $(1,1$ and 1).However, there is consensus among all the test frameworks in selecting lag length for this study as shown in appendix (II). Based on the principle underlying the ARDL approach to cointegration test and from the obtained result shown in table 4.2, the estimated F-Statistics $\left(\mathbf{4 . 8 0 9 7 7 6}^{* *}\right)$ is greater than upper bound critical value (3.87) at $\mathrm{K}=2$ and $5 \%$ significant level and therefore conclude that, there is long-run relationship between carbon tax and Nigerian economic growth.

\section{3: Estimation of Results}

\section{3: The ARDL con-integrating and Long Run Model (Panel A and B)}

\begin{tabular}{lllll}
\hline \multicolumn{4}{l}{ Panel A: Co-integrating Coefficients - Dependent variable is RGDP } & \\
\hline Regressor & Coefficient & Standard Error & T-Ratio & Prob. \\
\hline D(InCT) & -4.695064 & 23.461005 & -0.200122 & 0.8431 \\
D(GOV) & -0.140048 & 0.606806 & -0.230795 & 0.8194 \\
CointEq(-1) & -0.867284 & 0.202254 & -4.288088 & 0.0003 \\
\hline
\end{tabular}

Cointeq $=$ RGDP $-(+3.570545 *$ LOGCT $-0.303635 *$ GOV $)$

\section{Long-Run Coefficients (Panel B)}

\begin{tabular}{lllll}
\hline InCT & 0.358594 & 12.798256 & 0.028019 & 0.9779 \\
GOV & -0.581668 & 0.0806076 & -0.721604 & 0.4775 \\
C & 13.602874 & 162.594186 & 0.083662 & 0.9340 \\
\hline
\end{tabular}

Source: Author's Computation

The table 4.3 shows the result of the short-run and long-run relationship between the examined variables. From the table 4.3, it is shown that both carbon tax (-26.836673) and governance ($0.140048)$ are in short run negatively related to the economic growth. However, in the long-run, carbon tax $(0.358594)$ is positively related to economic growth; while governance $(-0.581668)$ 
is negatively related to economic growth, though both at insignificant statistical level. The result of ECM (-0.867284 and p-value 0.0003) is consistent to the apriori expectation of the theory showing that any disequilibrium in the short-run can speedily be amended back to the equilibrium level in the long-run by $86.7 \%$ speed of adjustment.

\section{2(b) Result of Toda-Yamamoto Causality Test}

Tables4.2.1 through 4.2.3 show the results causality test among the examinedvariables employed in the study. The results show that there is no causal relationship among the examined variables in all cases of individual dependent variable. This is because all the corresponding pvalues of the respective excluded variables are statistically insignificant at $5 \%$ or 0.05 statistical level. Similarly, all the variables under examination jointly do not granger cause economic growth in Nigeria for the reason that their respective joint $p$-value is greater than 0.05 or $5 \%$ level of statistical significance.

Table 4.2.1: Dependent Variable: RGDP

\begin{tabular}{cccc}
\hline Excluded & Chi-sq & Df & Prob. \\
\hline InTCT & 0.003685 & 1 & 0.9516 \\
GOV & 0.801917 & 1 & 0.3705 \\
\hline All & 0.802073 & 2 & 0.6696 \\
\hline
\end{tabular}

Source: Author's Computation

Table 4.2.1: Dependent Variable: InTCT

\begin{tabular}{cccc}
\hline Excluded & Chi-sq & Df & Prob. \\
\hline RGDP & 1.081431 & 1 & 0.2984 \\
GOV & 1.002380 & 1 & 0.3167 \\
\hline All & 2.246784 & 2 & 0.3252 \\
\hline
\end{tabular}

Source: Author's Computation

Table 4.2.3: Dependent Variable: GOV

\begin{tabular}{cccc}
\hline Excluded & Chi-sq & Df & Prob. \\
\hline RGDP & 0.852056 & 1 & 0.3560 \\
InTCT & 3.498442 & 1 & 0.0617 \\
\hline All & 4.198442 & 2 & 0.1226
\end{tabular}

Source: Author's Computation 


\section{4: Residual Diagnostic Tests}

The results of diagnostic tests shown in the table 4.4 indicate that the results of estimated models are free from such problems as serial correlation, heteroskedacity, normality of distribution, autocorrelation and adjusted coefficient of determination that leads to spurious regression results and that the model is stabled.

\section{Table 4.4: Result of Residual Diagnostics}

Tests

\section{Outcomes}

\section{Coefficients Probability}

Heteroskedasticity: Breusch-Pagan-Godfrey test F-stat. $\quad 0.311832 \quad 0.8166$

$$
\mathbf{N R}^{2} 1.050467 \quad 0.7890
$$

Breusch-Godfrey Serial Correlation LM TestF-stat.0.071451

0.9313

$$
\begin{array}{lll}
\mathbf{N R}^{2} & 0.180702 & 0.9136
\end{array}
$$

Normality Test

J/Berra1.4023943 0.4960

Ramsey-RESET

F-stat. 2.496133

0.1278

$\mathrm{R}^{2} 0.690165$

Adjusted R²0.492997

DW 2.193196

F-Statistics

3.500393

Prob. (F-Stat) 0.031503 


\section{Fig.4.1: Stability Test (CUSUM)}

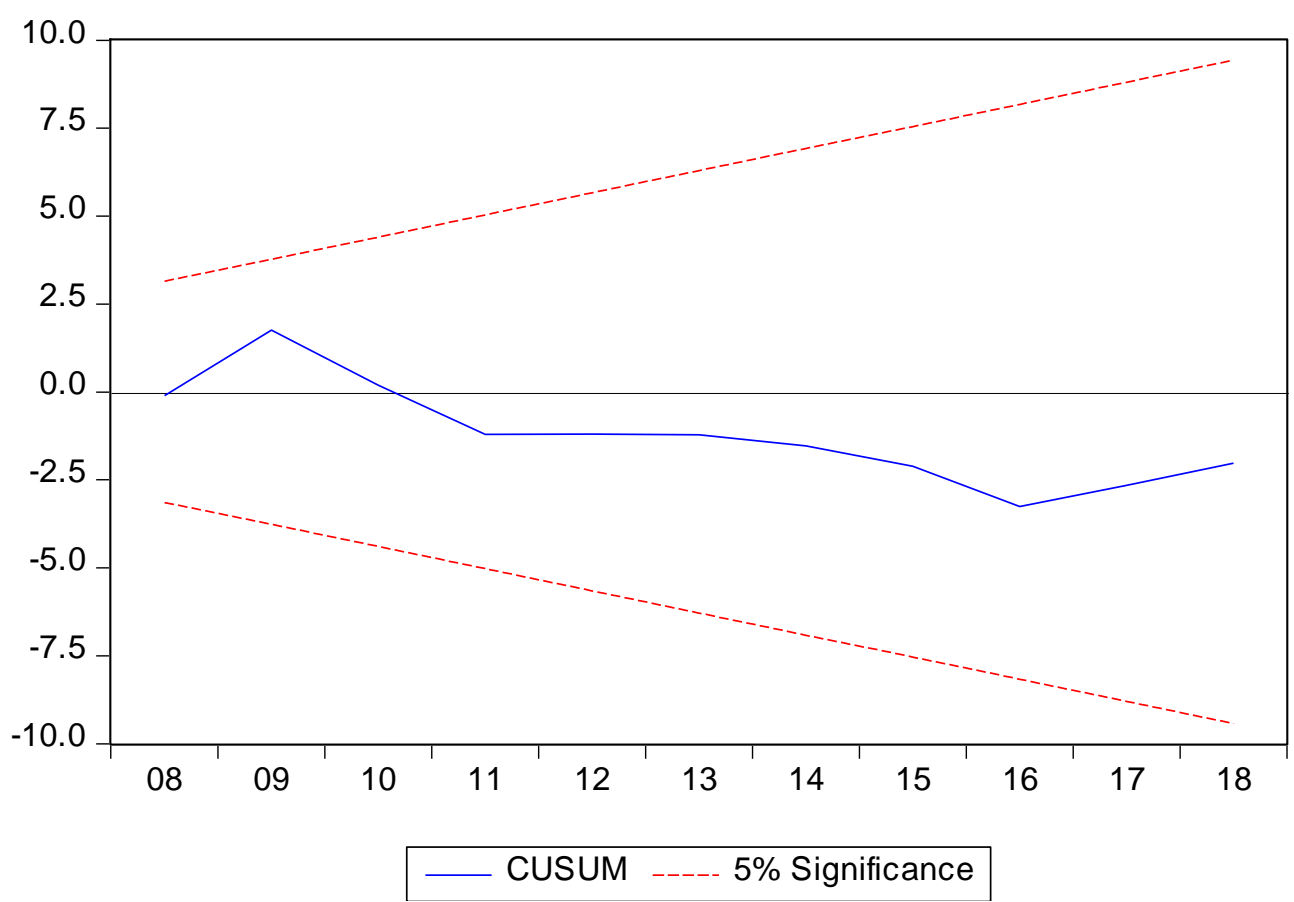

Fig. 4.2: Stability Test (CUSUM of Square)

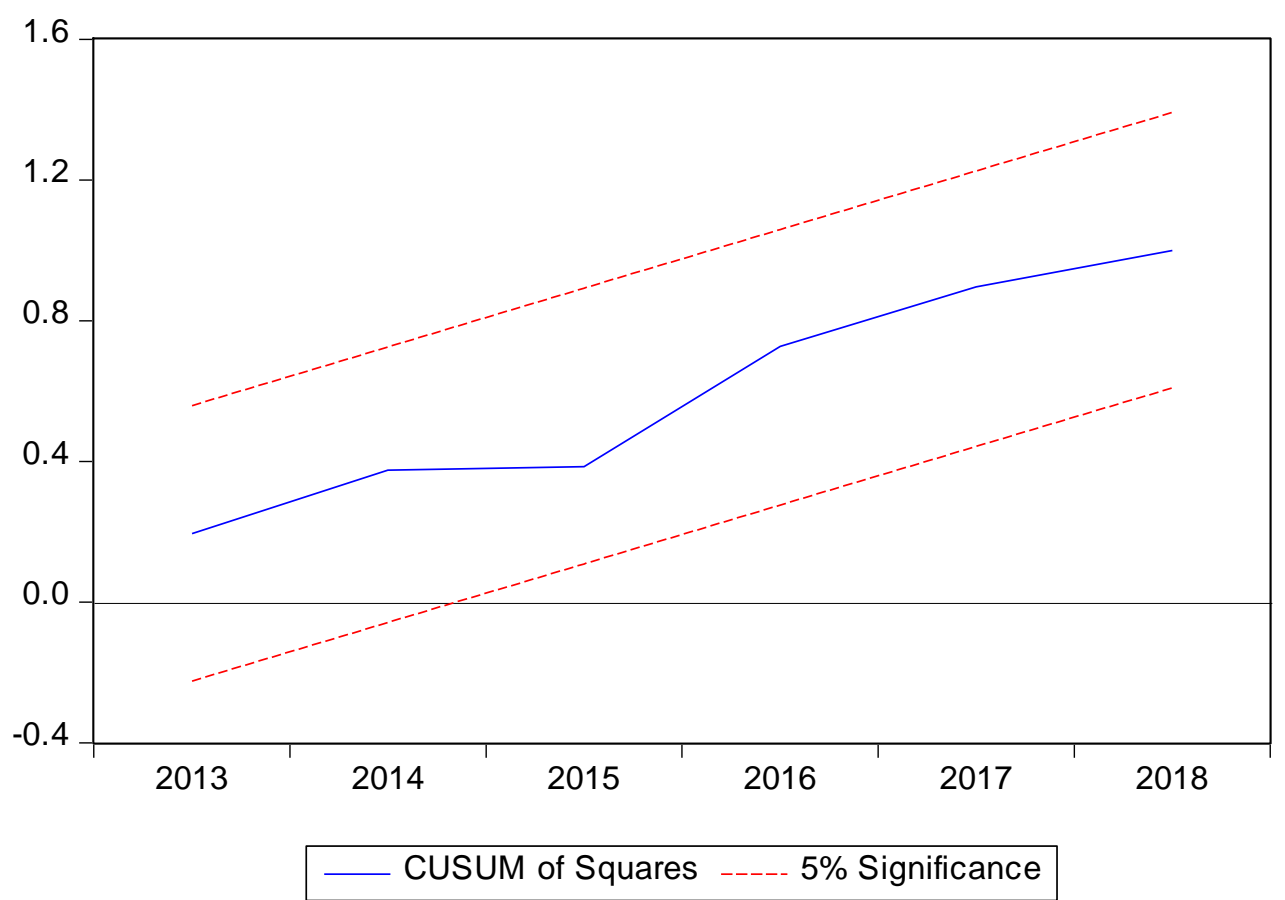




\subsection{Interpretations and Discussion}

The estimated results in Table 4.3 show that both carbon Tax and governance is in both the short-run and long-run impacted on the Nigerian economic growth; though at insignificant level of statistics. Discussion of results for the respective variable employed is presented below;

4.3.1: Carbon Tax: The positive coefficient of carbon tax (0.358594) implies that it impacts on the growth of Nigerian economy. This is consistent to the findings of Lin and Li (2011); Andersson (2015). But statistical insignificant of the result ( $p$-value $=0.8952$ ) is also consistent to the study of Lin and Lin and $\mathrm{Li}$ (2011). And by implication, carbon tax serves as regulation to the carbon emissiongenerating productive activities andincrease revenue base for the growth of economy, as such, it haspotentials to provide defence to the sustainable environment against the dangers of carbon emission generating activities thereby guaranteeing low carbon economy through adoption of environmental friendly input factors for attainment of sustainable growth and development in an economy; while statistical insignificant of the result is due to less effective governance in determining the appropriate tax rate per ton of carbon emission and less-effective enforcement of carbon tax rate in Nigeria as discussed below.

4.3.2: Governance: Also, the governance impacts on sustainable growth and development of Nigerian economy. The negative coefficient of GOV (-0.581668) implies inefficiency of the government apparatus in enforcing measures like carbon tax, promoting low carbon economy in a bid to achieve sustained growth and development of an economy. This is also conforming to the findings of Castiglione et al. (2014). The implication of this is that, the influence of governance in protecting the natural environment from impending dangers of carbon emission generating activities through imposition of tax on carbon emission related activities to sustained growth and development is defeated occasioned by the less effective system of tax administration in Nigeria.

\section{Summary and Conclusion}

This study employed an ARDL regression technique and Toda-Yamamoto causality test framework to investigate the potential impacts of carbon tax on economic growth and causal relationship between carbon tax and economic growth in Nigeria. The study begins with the test for stochastic property of the variables employed in the study using ADF unit root test framework which was followed by ARDL cointegration test to establish the presence of longrun equilibrium between carbon tax and economic growth and the ARDL regression model to evaluate impact of carbon tax on economic growth as well as Toda-Yamamoto to determine the causal relationship between carbon tax and economicgrowth in Nigeria. In this direction, the estimated long-run model revealed that carbon tax positively impacts on economic growth in Nigeria; while governance was in the estimated model shown negatively impacted on economic growth in Nigeria. Though, the magnitudes of both impact of carbon tax and governance on economic growth were found insignificant statistically. Similarly, the Toda-Yamamoto causality test in the study revealed non-existence of causal relationship between carbon tax and economic growthin Nigeria.The study then recommends:

i. Upward review of carbon tax rate per ton of carbon emission as Nigerian carbon tax is found below that of other countries with similar policy direction on environmental consequences of carbon emission on economy. 
International Journal of Advanced Academic Research (Social and Management Sciences) | ISSN: 2488-9849

Journal DOI: 10.46654/ij.24889849

Vol. 6, Issue 10 (October, 2020) | www.ijaar.org

Article DOI: 10.46654/ij.24889849.e61013

ii. Strict adherence to the rules governing tax on carbon emission related activities shouldbe enforced.

iii. Emphasis must not only be restricted to the imposition of carbon tax on primary emitters of carbon but be broadened to encompass all carbon emitting activities in the country. 


\section{References:}

Al-Abdullah, A. Y. (1999). The Carbon-tax debate.Applied energy, 64(1), 3-13. https://doi.org/10.1016/S0306-2619(99)00105-1

Andersson, J. (2015). Cars, carbon taxes and CO2 emissions. London. Grantham Research Institute on Climate Change and the Environment, 2015.

Baranzini, A. \&Garattini, S. (2014). Taxation of emissions of greenhouse gases.InGlobal Environmental Change, edited by Bill Freedman, 543-560.

Bernd, H. (2000). "The influence of Knut Wicksell on Richard Musgrave and James Buchanan".Public Choice", 103(1/2), pp. 95-116.

Bowen, A.(2011). The case for carbon pricing.Grantham Research Institute on Climate Change and the Environment, Policy Brief, December. Available at: http://www.lse.ac.uk/GranthamInstitute/wp-content/uploads/2014/02/PB_case-carbonpricing_Bowen.pdf.

CAIT (2016).Country greenhouse gas emissions datasets.CAIT Climate data Explorer. Available on: https://www.wri.org

Castiglione, C., Infante, D., Minervini, M. T., \&Smirnova, J. (2014). Environmental taxation in Europe: What does it depend on? Cogent Economics \& Finance, 2(1),962-967. https://doi.org/10.1080/23322039.2014.967362

Central Bank of Nigeria (2019).Functional classification of Federal government expenditure in Nigeria. CBN Publication, Nigeria.

Chindo, S.\& Abdul-Rahim, A. S. (2018).Population growth and CO2 emission in Nigeria.A recursive ARDL approach.SAGE Open, 1(1), 1-14.

Eunho, C. Almas, H. \&Yongsung, C. (2010).Empirical study of the relationship between carbon emission and economic growth and openness. Discussion paper, No. 5304, IZA, bonn Germany.

Galeotti, M., Manera, M. \&Lanza, A. (2009).On the robustness of robustness checks of the environmental Kuznets curve.Environmental and Resource Economics, 42(1), 551-574.

Garber, P. M. (2011).The effect of industrialization on the environment. Cambridge: MIT Press.

Grossman, G. M. (2009). Economic growth and the environment.The Quarterly Journal of Economics, 110 (1), 353-377.

Guo, Z., Zhang, X., Zheng, Y., \&Rao, R. (2014).Exploring the impacts of a carbon tax on the Chinese economy using a CGE model with a detailed disaggregation of energy sectors.Energy Economics, 45, 455-462. https://doi.org/10.1016/j.eneco.2014.08.016

Hamilton, J.D. (1994). Time Series Analysis, Princeton University Press, Princeton, New Jersey.

ICRG (2017). Political risk ratings for 140 countries:1984-2017. Available on: https://www.prsgroup.com 
Kalkuhl, M. (2013). Renewable energy subsidies: second-best policy or fatal aberration for mitigation. Resources and Energy Economics, 35(3), 217-234.

KPMG (2015).Taxes and incentives for renewable energy. KPMG, International,Swiss. Available:http://www.internationalinsurance forrenewable-energy.pdf .org/files/TC/PDF/taxes-incentives-

Lin, B., \& Li, X. (2011).The eff ect of carbon tax on per capita co2 emissions.Energy Policy, 39(9), 5137-5146. Retrieved from: http://www.sciencedirect.com/ science/article/pii/S0301421511004502 doi: http://dx.doi.org/10.1016/j.enpol.2011 .05 .050

Lütken, S.Fenhann, J.Hinostroza, M. Sharma, S.\&Olsen, K. H. (2011).Low carbon development strategies. United Nation Environmental Programme (UNEP, 2011) Available:http://www.namapipeline.org/Publications/LowCarbonDevelopmentStrategi_N AMAprimer.pdf

Mesih, R.A.\&Mesih,T. (2009). Causality between income and emission: A Country Group Specific Econometric Analysis.Ecological Economics, 40(1), 351-367.

Mojtaba,

K.,Alireza,

A.

\&Mehdi, N. (2020).HowdoescarbontaxaffectsocialwelfareandemissionreductioninFinland?Energy Reports 6(2020), 736-744. Elsevier.

OECD(2015).Aligning policies for a low-carbon economy.Produced in cooperation with the international energy agency, international transport forum, and nuclear energy agency.Organisation for Economic Co-operation and Development, Paris. Available at: http://dx.doi.org/10.1787/9789264233294-en

Opeyemi, A., Philip, O. A., Oluseyi. O. A. \& Henry, O. (2017). Energy pricing policy and environmental quality in Nigeria: A dynamic computable general equilibrium approach. International Journal of Energy Economics and Policy, 7(1), 268-276.

Parry, I., Heine, D., \&Veung, C. (2015). How much carbon pricing is in countries own interest? The critical role of co-benefits.Climate Change Economics, 6(1), 1-26.

Pesaran, M. H., Shin, Y., \& Smith, R. J. (2001).Bounds testing approaches to the analysis of level relationships. Journal of Applied Econometrics, 16, 289-326.

Precious, C. A. (2017).Climate policy and finance: Designing an effective carbon pricing system for Nigeria's oil and gas sector. A working Paper presented at Centre for the Study of the Economies of Africa, 4 Dep. Street, Off Danube StreetMaitama, Abuja FCT, Nigeria.

Richard, A. M. \& Peggy, B. M. (1973).Public finance in theory and practice."The theory of social goods".Ctd. in Efficient provision of social goods, ch. 3, p.68.

Saidi, K. \&Hammami, S. (2015). The impact of carbon emission and economic growth on energy consumption in 58 countries.Energy Report, Elsevier, Amsterdam, 1(3), 62-70. Available on: http://dx.doi.org/10.1016/j.egyr.2015.01.003 
Seldon, T.\& Song, D. (2004). Environmental quality and development: Is there a kuznet curve for air pollution emissions? Journal of Environmental Economics and Management, 147162.

Stephen, A. E. (2014).Impact of carbon emissions on economic growth in Nigeria.Asian Journal of Basic and Applied Sciences, 1(1), 15-25.

UN (2015).Transforming our World: The 2030 Agenda for Sustainable Development.United Nations Sustainable Development Report, 2015. 


\section{Appendix I}

Fig.1

LOGCT

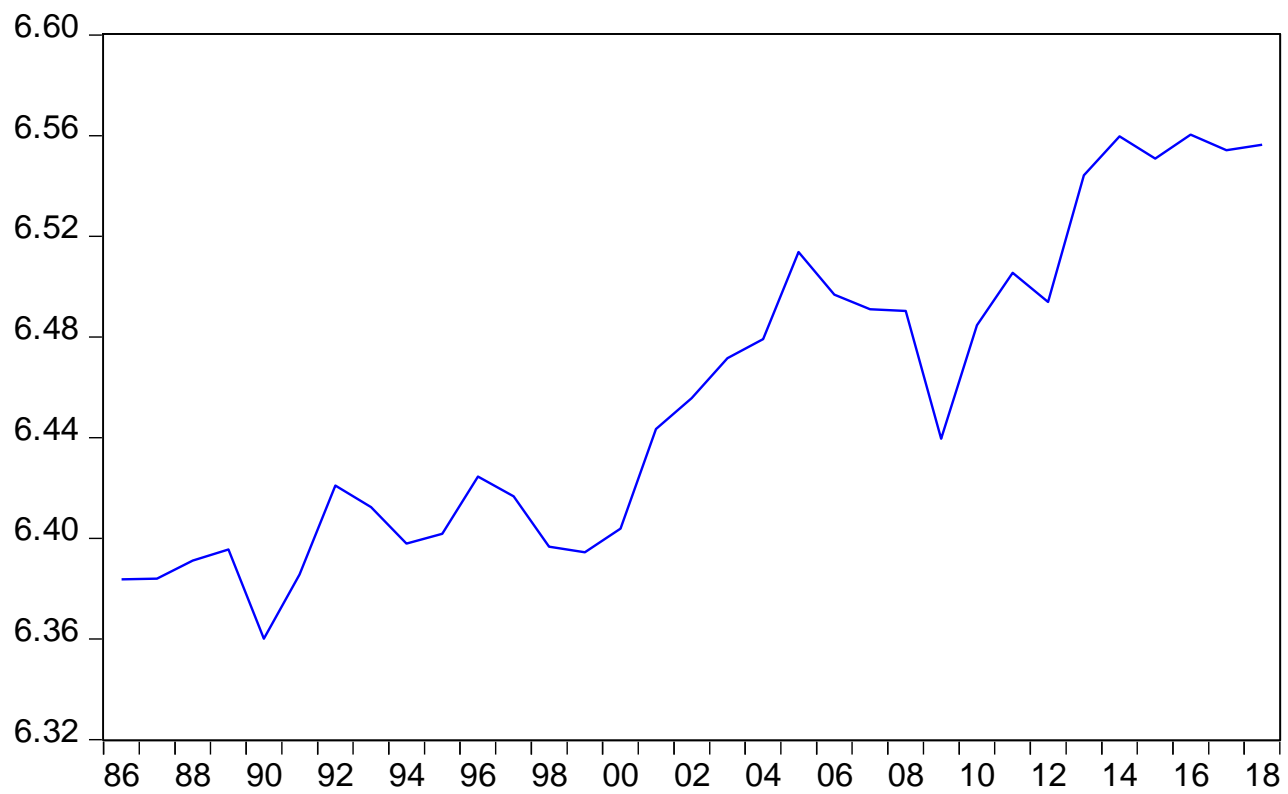

Fig.2

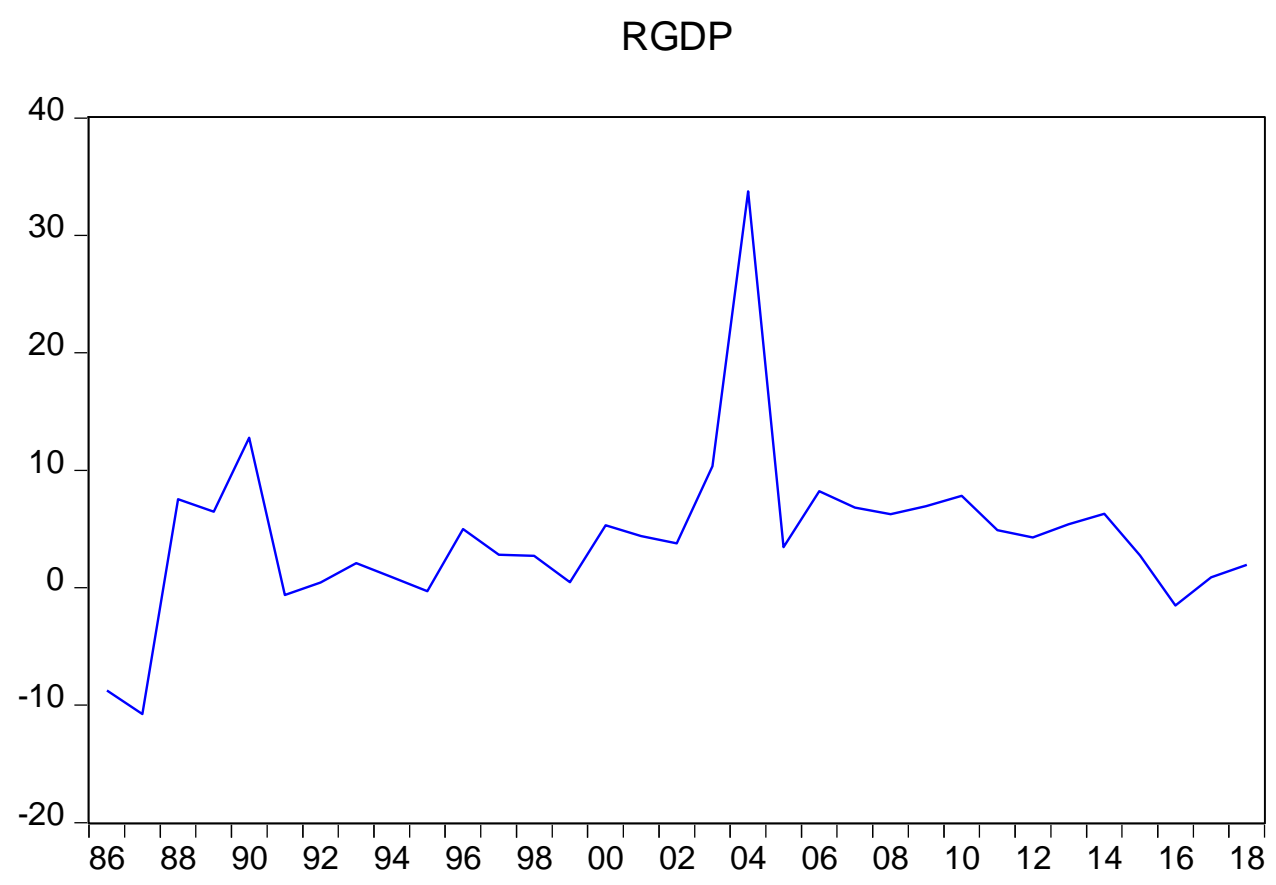


Fig.3

GVC

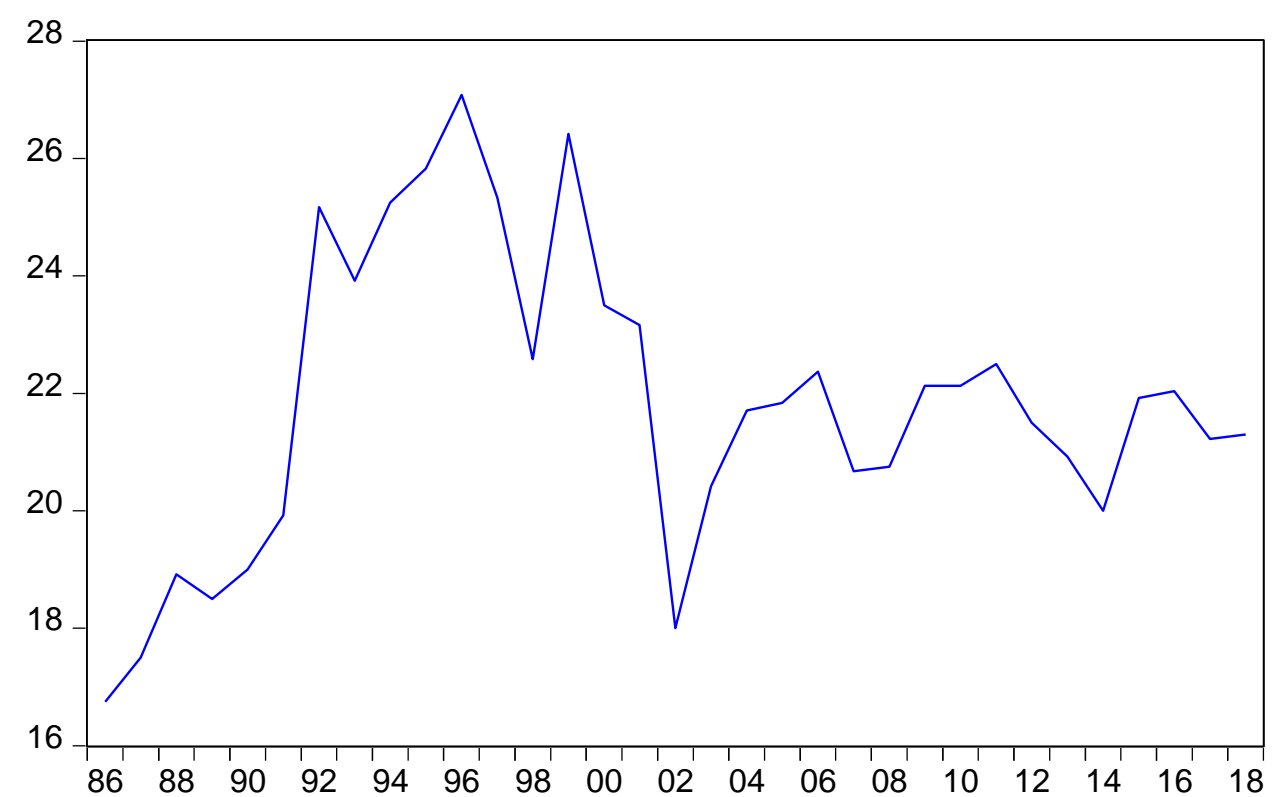

Appendix II

Result of Correlation Matrix

\begin{tabular}{llll} 
Variables & RGDP & LOGCT & GOV \\
\hline
\end{tabular}

RGDP $\quad 1.000000$

$\begin{array}{lll}\text { LOGCT } & 0.036193 & 1.000000\end{array}$

GOV $-0.267280-0.397158 \quad 1.000000$

Source: Authors Computation

\section{Appendix III}

\section{Lag Length selection}

\begin{tabular}{cccllll}
\hline Lag & LogL & LR & FPE & AIC & SC & HQ \\
\hline 0 & -120.7053 & NA & 1.915213 & 9.163359 & 9.307340 & 9.206172 \\
1 & -90.34331 & $51.72791 *$ & $0.396113^{*}$ & $7.580986^{*}$ & $8.156913^{*}$ & $7.752239^{*}$ \\
2 & -88.09537 & 3.330273 & 0.672897 & 8.081139 & 9.089012 & 8.380832
\end{tabular}

Source: Author's Computation 